Egypt. Acad. J. Biolog. Sci., 11(2): 99- 110 (2019)

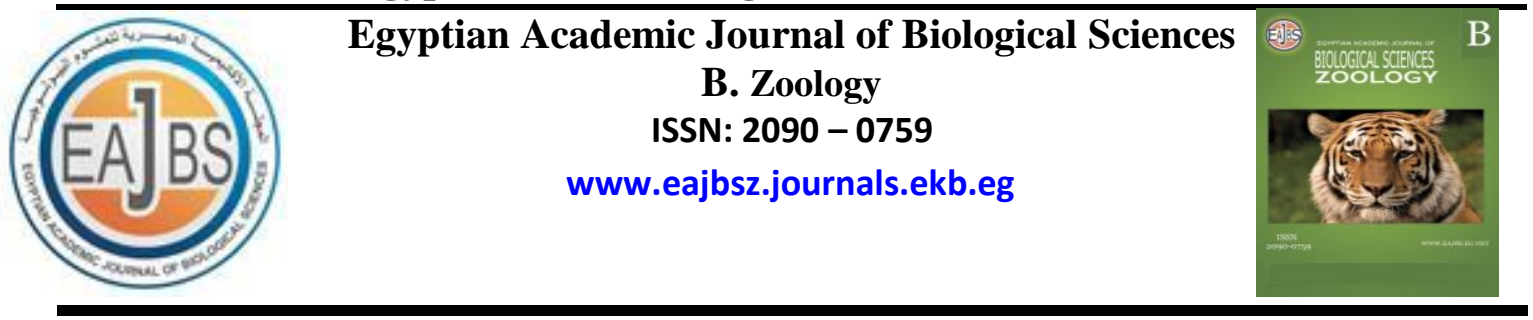

\title{
Dynamics of Crustacean Larvae Composition and Abundance in Mesohaline Creeks of Lagos Lagoon, Nigeria
}

\author{
Lawal-Are, A.O. ${ }^{1}$, Moruf, R.O. ${ }^{2 *},{ }^{1}$ Amosu, A.I. ${ }^{1}$ and ${ }^{1}$ S.O. Sadiq \\ ${ }^{1}$ Department of Marine Sciences, University of Lagos, Akoka, Lagos State- Nigeria \\ ${ }^{2}$ Department of Fisheries and Aquaculture, Bayero University, Kano, Kano State- Nigeria \\ E.Mail.: tunjimoruf@gmail.com, romoruf.faq@buk.edu.ng
}

ARTICLE INFO

Article History

Received:27 /5/2019

Accepted:2/7/2019

Keywords:

Crustacean, Water

chemistry, Larvae, AbuleAgege Creek, Abule-Eledu Creek
The physicochemical flux, composition and abundance of crustacean larvae in two mesohaline creeks of Lagos Lagoon were investigated. The status of the Physico-chemical parameters indicates a non-significant difference between variables except Alkalinity with Abule-Eledu Creek having significantly higher mean value (144.4 \pm 2.2 $\mathrm{mg} / \mathrm{L})$ than Abule-Agege Creek $(121.9 \pm 4.9 \mathrm{mg} / \mathrm{L})$. The transparency values of the creeks increased with a reduction in the amount of rainfall while the water temperature as well as salinity values increased appreciably with the dry season. An increase in conductivity $(>190.40 \mu \mathrm{S} / \mathrm{cm})$ and salinity $(>10.50 \%)$ in the dry months for both creeks was also observed. The crustacean larvae were represented by five orders with Calanoida and Cyclopoida (Sub-Class: Copepoda) were the most frequent and notable orders occurring in Abule-Eledu and Abule-Agege creeks respectively. Other crustacean categories such as Mysida, Calanoida and Harpaticoida were also recorded. Total species diversity was 14 in Abule-Eledu creek and 17 in Abule-Agege Creek. Shannon-Wiener Index values ranged between 0.90 and 0.96 for Abule-Eledu Creek and between 0.97 and 1.09 for Abule-Agege Creek. With the exception of Menhinick Index and Equitability Index, all other biotic indices were higher in Abule-Agege Creek than AbuleEledu creek. This study therefore suggests that Calanoida and Cyclopoida which are orders of the subclass Copepoda are the dominant crustacean zooplankton group in the creeks of the Lagos Lagoon

\section{INTRODUCTION}

Crustaceans form a very large and diversified group of arthropods, which includes known animals as crabs, lobsters, crayfish, shrimp, krill and barnacles ranging in size from $0.1 \mathrm{~mm}$ to the Japanese spider crab with a leg span of up to $3.8 \mathrm{~m}$ and a mass of $20 \mathrm{~kg}$ (Rota-Stabelli et al., 2010). In most crustacea, development is accompanied by little or more metamorphosis and the various stages of development are known as larvae. They are nauplius, metanauplius, cypris, kentrogen, protozoea, zoea, metazoea, calyptosis, erichthus, alima, megalopa, glaucothoea, mysis and phyllosoma (Addis et al., 2007). Each of the stages is separated by a moult, in which the hard exoskeleton is shed to allow the animal to grow. Most larvae of crustaceans 
are lecithotrophic (consuming egg yolk) while others are planktotrophic (feeding on plankton) and often bear little resemblance to the adult.

The occurrence and distribution of plankton fauna depend on a number of factors such as climate change, habitat physicochemical properties, and biotic factors (Ahmad et al., 2011; Alexander, 2012). Environmental factors are important elements; for instance, water temperature impacts the growth and development of organisms and can influence their mortality (Hall and Burns, 2001). Different species show varied tolerances to increases or reductions in temperature ranges, and particularly sensitive individuals are eliminated by them. The larva of invertebrate can be prompted to migrate in order to avoid the unfavorable environmental condition. The presence of three stages of larval development of $C$. amnicola (early zoea larval stage, late zoea larval stage and megalopa) observed in the plankton haul in the Lagos lagoon has been reported by Lawal-Are (2009).

Previously documented studies on the effects of water chemistry on the zooplankton community structure of Lagos Lagoon include the works of Edokpayi and Nkwoji (2007), Onyema and Ojo (2008), Lawal-Are et al. (2010) and Nkwoji et al. (2010). However, there is a dearth of information on the influence of environmental variables specifically on crustacean larvae. Therefore, the proper knowledge of their abundance and distribution in estuaries and response to variable ecological abiotic components can serve as a guide for ensuring sustainable management of its fishery. This study attempted to investigate the distribution and assemblage structure of crustacean larvae in relation to the environmental parameters of Abule-Agege and Abule Eledu creeks of the Lagos Lagoon.

\section{MATERIALS AND METHODS}

\section{The Study Area:}

Abule -Agege and Abule-Eledu creeks form part of the many sluggish tidal creeks that drain into the Lagos Lagoon. Global positioning system (GPS) of the study areas are $6^{\circ} 30^{\prime} \mathrm{N}$ and $3^{\circ} 24^{\prime} \mathrm{E}$ (Abule -Agege) and $6^{0} 31.01^{\prime} \mathrm{N}$ and $3^{0} 23.95^{\prime} \mathrm{E}$ (AbuleEledu creek). The creeks are shallow $(\leq 1 \mathrm{~m})$ and meander through a mangrove swamp which is inundated at high tide and partially exposed at low tide (Moruf and LawalAre, 2015).

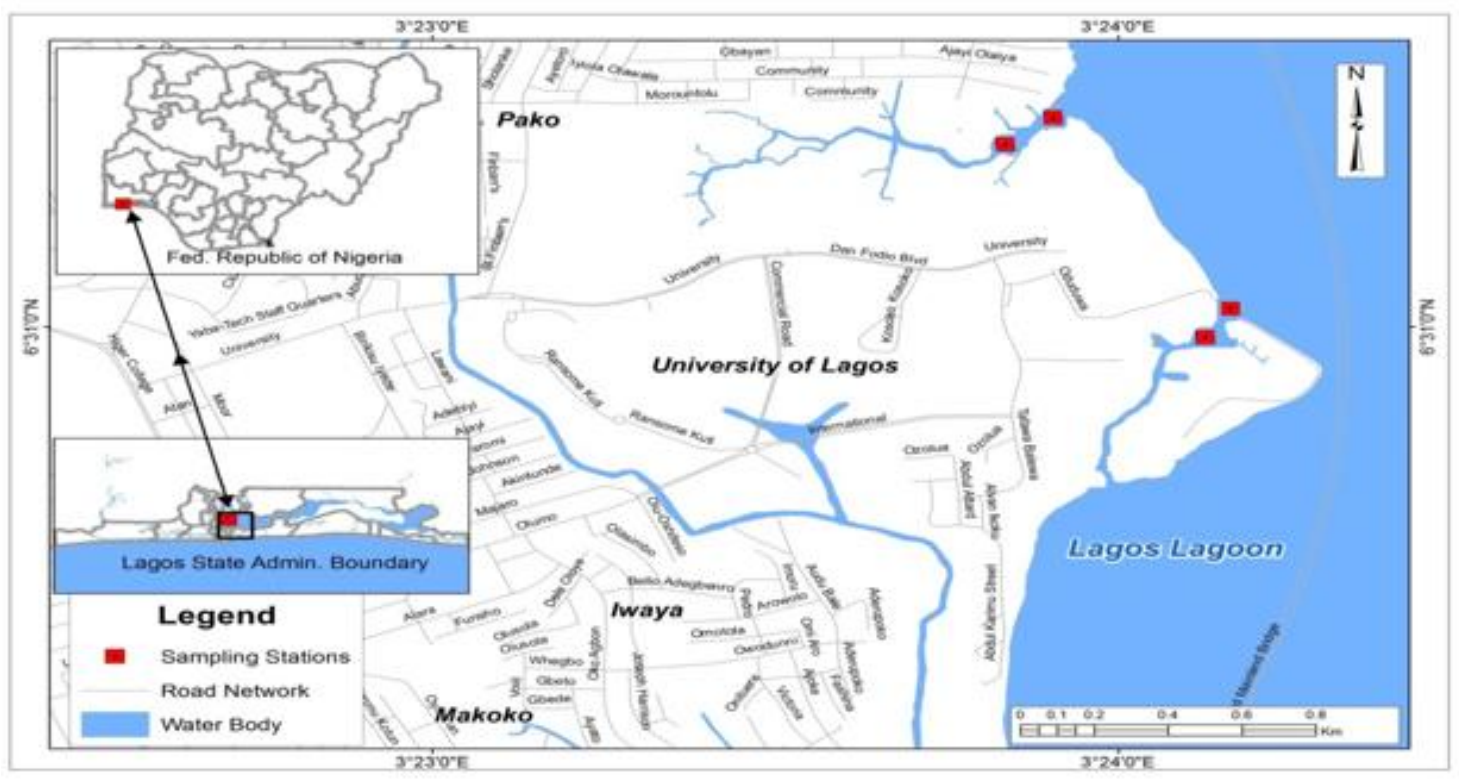

Fig. 1: Map Showing the Lagos Lagoon Adjacent Creeks 


\section{Collection of Water and Larvae Samples:}

Surface water samples were collected from the creeks with $500 \mathrm{ml}$ plastic containers fortnightly between April and July (2017). The samples were collected from four sampling stations (two/creek) between the hours of 8:00 am - 10:00 am. The labeled containers were immediately taken to the laboratory for further water chemistry analysis. The larvae samples were collected using a plankton net of $15 \mathrm{~cm}$ diameter and mesh size $55 \mu \mathrm{m}$ according to the procedure described by Verlencar and Desai (2004). The samples were immediately preserved with $5 \%$ formalin and stored prior to microscopic analysis (Wetzel and Likens, 2000).

\section{Laboratory Analysis:}

Air and surface water temperatures were measured in-situ using a mercury-inglass thermometer while water depth was estimated with a calibrated pole. The physiochemical parameters were determined as described by APHA (2005). Plankton samples were allowed to settle and concentrated by filtering. After condensing to $10 \mathrm{mI}$, $1 \mathrm{ml}$ of subsample was withdrawn for sorting and counting using a light microscope. Identification of the crustacean larvae to species level was done using keys described by Lynne (2004), Sanet et al. (2006) and Suthers and Rissik (2009) while Drop Count Method described by Onyema (2007) were made in triplicates and their averages were taken. Larvae abundance was estimated using the formula described by Goswami (2004).

\section{Crustacean Larvae Community Structure:}

The below equations are quoted according to Ogbeibu, (2005):

- Species richness index: Margalef index was used to assess community structure for the crustacean larvae spectrum.

$$
d=\frac{s-1}{\operatorname{Ln} N}
$$

$\mathrm{d}=$ Species richness index

$\mathrm{S}=$ Number of species in a population

$\mathrm{N}=$ Total number of individuals in $\mathrm{S}$ species.

\section{- Shannon and Wiener diversity index (Hs):}

Where

$$
\boldsymbol{H} \boldsymbol{s}=\frac{N \log N-\sum P i \log P i}{N}
$$

Hs = Shannon and Wiener diversity Index

$\mathrm{i}=$ Counts denoting the ith species ranging from $1-\mathrm{n}$

$\mathrm{Pi}=$ Proportion that the ith species represents in terms of numbers of individuals with respect to the total number of individuals in the sampling space as a whole

- Species Equitability or Evenness index (j):

Where

$$
J=\frac{H s}{\log 2 s}
$$

$\mathrm{J}=$ Equitability index

$\mathrm{Hs}=$ Shannon and Weiner index

$\mathrm{S}=$ Number of species in a population

- Simpsons dominance index $(\mathrm{C})$ :

Where

$$
C=\Sigma\left(\frac{n i}{N}\right)^{2}
$$

$\mathrm{n}=$ the total number of organisms of a particular species

$\mathrm{N}=$ the total number of organisms of all species 


\section{RESULTS}

\section{Physicochemical Flux:}

The monthly variations in water quality indices at the Abule-Eledu and AbuleAgege creeks linked to the Lagos Lagoon between April and July (2017) are shown in Table 1and 2 respectively while the comparison is shown in Table 3. In Abule-Eledu Creek, Air temperature ranged from $30^{\circ} \mathrm{C}$ in July to $32^{\circ} \mathrm{C}$ in May while Water temperature ranged from $27.5^{\circ} \mathrm{C}$ in July to $31.1^{\circ} \mathrm{C}$ in May. Transparency values ranged from 32.6 in July to $46.5 \mathrm{~cm}$ in April. The highest rainfall $(431.74 \mathrm{~mm})$ was recorded in the month of July while the lowest $(110.6 \mathrm{~mm})$ in the month of April. PH (at $25^{\circ} \mathrm{C}$ ) was between 6.7 and 7.7 (7.1 \pm 0.3$)$. Values of conductivity fluctuated between 5478 (July) and $29451 \mathrm{~S} / \mathrm{cm}$ (April) when Total Dissolved Solids (TDS) and Total Suspended Solids (TSS) range between 3253 and $16833 \mathrm{mg} / \mathrm{L}(10901.1 \pm 6.2)$ and 13 and $16.3 \mathrm{mg} / \mathrm{L}(13.7 \pm 1)$ respectively. Salinity varied between 3.0 (July) and $17.2 \%$ (April) while turbidity was between 9.6 and 21.1 (14.2 \pm 2.5 ). Acidity ranged from 5.8 to $8.8 \mathrm{mg} / \mathrm{L}(8.3 \pm 0.9)$ while Alkalinity was between 138.9 and $148.75 .8 \mathrm{mg} / \mathrm{L}$ (144.4 \pm 2.2 ). The lowest value for dissolved oxygen recorded was $5.1 \mathrm{mg} / \mathrm{L}$ and the highest value was $5.6 \mathrm{mg} / \mathrm{L}$. Furthermore, Biological oxygen demand and chemical oxygen demand were between 4.2 and $6.8 \mathrm{mg} / \mathrm{L}(5.1 \pm 0.6)$ and 8.9 and $28 \mathrm{mg} / \mathrm{L}$ (19.0 \pm 3 .) respectively. Value for nitrate was between 2.6 and $8.7 \mathrm{mg} / \mathrm{L}(6.0 \pm 1.4)$ while the lowest value $(0.6 \mathrm{mg} / \mathrm{L})$ of phosphate was recorded in April and the highest $(2.5$ $\mathrm{mg} / \mathrm{L})$ in July.

Table 1: Monthly Physico-Chemical Flux of Abule-Eledu Creek (April - July, 2017)

\begin{tabular}{|c|c|c|c|c|c|}
\hline Parameter & April & May & June & July & Mean \pm SEM \\
\hline Air Temperature $\left({ }^{\circ} \mathbf{C}\right)$ & 31.2 & 32 & 31 & 30 & $31.1 \pm 0.4$ \\
\hline Water Temperature $\left({ }^{\circ} \mathbf{C}\right)$ & 30.7 & 31.1 & 29.5 & 27.5 & $29.7 \pm 0.8$ \\
\hline Transparency $(\mathrm{cm})$ & 46.5 & 33 & 32.7 & 32.6 & $36.2 \pm 3.4$ \\
\hline Rainfall (mm) & 110.6 & 125.8 & 299.6 & 431.7 & $241.9 \pm 6.4$ \\
\hline pH at $25^{\circ} \mathrm{C}$ & 7.4 & 7.7 & 6.7 & 6.7 & $7.1 \pm 0.3$ \\
\hline Conductivity $(\mu \mathrm{S} / \mathrm{cm})$ & 29451 & 26088 & 15598 & 5478 & $19154 \pm 9.7$ \\
\hline $\begin{array}{l}\text { Total dissolved solid } \\
\text { (mg/L) }\end{array}$ & 16833 & 14120 & 9398 & 3253 & $10901 \pm 6.2$ \\
\hline $\begin{array}{l}\text { Total suspended solid } \\
\text { (mg/L) }\end{array}$ & 13.8 & 11.8 & 16.3 & 13 & $13.7 \pm 1$ \\
\hline Salinity (ppt, at $25^{\circ} \mathrm{C}$ ) & 17.2 & 15.3 & 9 & 3 & $11.1 \pm 3.2$ \\
\hline Turbidity (NTU) & 11.9 & 14 & 21.1 & 9.6 & $14.2 \pm 2.5$ \\
\hline Acidity (mg/L, CaC03) & 5.8 & 9.8 & 8.7 & 8.8 & $8.3 \pm 0.9$ \\
\hline Alkalinity (mg/L, CaC03) & 138.9 & 148.7 & 143 & 147.1 & $144.4 \pm 2.2$ \\
\hline Dissolved oxygen (mg/L) & 5.1 & 5.1 & 5.2 & 5.6 & $5.3 \pm 0.1$ \\
\hline $\begin{array}{l}\text { Biological oxygen } \\
\text { demand }(\mathrm{mg} / \mathrm{L})\end{array}$ & 6.8 & 4.2 & 5.3 & 4.2 & $5.1 \pm 0.6$ \\
\hline $\begin{array}{l}\text { Chemical oxygen demand } \\
(\mathrm{mg} / \mathrm{L})\end{array}$ & 28 & 19.2 & 19.8 & 8.9 & $19.0 \pm 3.9$ \\
\hline Nitrate (mg/L as NO3) & 8.7 & 8.1 & 2.6 & 4.7 & $6.0 \pm 1.4$ \\
\hline Phosphate (mg/L) & 0.6 & 1.4 & 1.3 & 2.5 & $1.5 \pm 0.4$ \\
\hline
\end{tabular}

Demand and chemical oxygen demand were between 4.2 and $6.8 \mathrm{mg} / \mathrm{L}$ $(5.1 \pm 0.6)$ and 8.9 and $28 \mathrm{mg} / \mathrm{L}(19.0 \pm 3$.) respectively. Value for nitrate was between 
2.6 and $8.7 \mathrm{mg} / \mathrm{L}(6.0 \pm 1.4)$ while the lowest value $(0.6 \mathrm{mg} / \mathrm{L})$ of phosphate was recorded in April and the highest $(2.5 \mathrm{mg} / \mathrm{L})$ in July.

Table 1: Monthly Physico-Chemical Flux of Abule-Eledu Creek (April - July, 2017)in Abule-Agege Creek, Air temperature ranged from 30 to $32^{\circ} \mathrm{C}$ with the mean $31.4 \pm 0.5$ while Water temperature ranged from 27.5 in July to $31.8^{\circ} \mathrm{C}$ in April. Transparency values ranged from 32.6 to $46.5 \mathrm{~cm}$, lowest was recorded in July and highest in April. Rainfall value was highest in July $(431.7 \mathrm{~mm})$ and lowest in April $(110.6 \mathrm{~mm})$. The $\mathrm{pH}\left(\right.$ at $\left.25^{\circ} \mathrm{C}\right)$ was slightly alkaline at average $(7.1 \pm 0.2)$. Conductivity values varied between 43923 (July) and $30550 \mu \mathrm{S} / \mathrm{cm}$ (April) whereas, Total Dissolved Solids (TDS) and Total Suspended Solids (TSS) range between 2637 and $17417 \mathrm{mg} / \mathrm{L}$ $(12724.9 \pm 2.9)$ and 8 and $13.5 \mathrm{mg} / \mathrm{L}(10.8 \pm 1.2)$ respectively. There were rise and fall in the values of salinity throughout the sampling period ranging between 2.3 (July) and $17.9 \%$ (April) while turbidity was between 7.2 and 16.2 (11.8 \pm 1.8$)$. Furthermore, Acidity ranged from 3.9 to $7.1 \mathrm{mg} / \mathrm{L}(5.8 \pm 0.7)$ while Alkalinity was between 115.1 and $136.1 \mathrm{mg} / \mathrm{L}(121.9 \pm 4.9)$. The lowest value for dissolved oxygen recorded was 5.2 $\mathrm{mg} / \mathrm{L}$ (April and May) and the highest value(July) was $5.8 \mathrm{mg} / \mathrm{L}$. Biological oxygen demand and Chemical oxygen demand were between 2.5 and $7.5 \mathrm{mg} / \mathrm{L}(4 . \pm 1)$ and 6 and $29.3 \mathrm{mg} / \mathrm{L}(18.5 \pm 5.3)$ respectively. Levels for nitrate ranged between 2.6 in June and $11.7 \mathrm{mg} / \mathrm{L}$ in July with higher phosphate value $(1.1 \mathrm{mg} / \mathrm{L})$ recorded in June and July while the lowest value $(0.5 \mathrm{mg} / \mathrm{L})$ was recorded in April.

The status of the physico-chemical parameters at the two mesohaline creeks of the Lagos Lagoon (Table 3) indicates a non-significant difference between variables except in Alkalinity with Abule-Eledu Creek having significant higher mean value $(144.4 \pm 2.2 \mathrm{mg} / \mathrm{L})$ than Abule-Agege Creek $(121.9 \pm 4.9 \mathrm{mg} / \mathrm{L})$.

Table 2: Monthly Physico-Chemical Flux of Abule-Agege Creek (April - July, 2017)

\begin{tabular}{|c|c|c|c|c|c|}
\hline Parameter & April & May & June & July & Mean \pm SEM \\
\hline Air Temperature $\left({ }^{\circ} \mathbf{C}\right)$ & 31.6 & 32 & 32 & 30 & $31.4 \pm 0.5$ \\
\hline Water Temperature $\left({ }^{\circ} \mathbf{C}\right)$ & 31.8 & 30.9 & 29.8 & 27.5 & $30.0 \pm 0.9$ \\
\hline Transparency $(\mathrm{cm})$ & 46.5 & 33 & 32.6 & 32.6 & $36.2 \pm 3.4$ \\
\hline Rainfall (mm) & 110.6 & 125.8 & 299.6 & 431.7 & $241.9 \pm 2.3$ \\
\hline pH at $25^{\circ} \mathrm{C}$ & 7.4 & 7.6 & 6.6 & 6.8 & $7.1 \pm 0.2$ \\
\hline Conductivity $(\mu \mathrm{S} / \mathrm{cm})$ & 30550 & 29850 & 22440 & 4392.7 & $21808.2 \pm 8.2$ \\
\hline $\begin{array}{l}\text { Total dissolved solid } \\
(\mathrm{mg} / \mathrm{L})\end{array}$ & 17417 & 17323 & 13523 & 2637 & $12724.9 \pm 2.9$ \\
\hline $\begin{array}{l}\text { Total suspended solid } \\
(\mathrm{mg} / \mathrm{L})\end{array}$ & 8 & 9.8 & 13.5 & 12 & $10.8 \pm 1.2$ \\
\hline Salinity (ppt, at $25^{\circ} \mathrm{C}$ ) & 17.9 & 17.3 & 13 & 2.3 & $12.6 \pm 3.6$ \\
\hline Turbidity (NTU) & 11.7 & 16.2 & 12 & 7.2 & $11.8 \pm 1.8$ \\
\hline Acidity (mg/L, CaC03) & 5.4 & 3.9 & 6.7 & 7.1 & $5.8 \pm 0.7$ \\
\hline Alkalinity (mg/L, CaC03) & 136.1 & 116.3 & 115.1 & 120.1 & $121.9 \pm 4.9$ \\
\hline Dissolved oxygen $(\mathrm{mg} / \mathrm{L})$ & 5.2 & 5.2 & 5.3 & 5.8 & $5.4 \pm 0.1$ \\
\hline $\begin{array}{l}\text { Biological oxygen demand } \\
(\mathrm{mg} / \mathrm{L})\end{array}$ & 7.5 & 5.3 & 4.3 & 2.5 & $4.9 \pm 1$ \\
\hline $\begin{array}{l}\text { Chemical oxygen demand } \\
\text { (mg/L) }\end{array}$ & 29.3 & 24.8 & 14 & 6 & $18.5 \pm 5.3$ \\
\hline Nitrate (mg/L as NO3) & 5.4 & 5.1 & 2.6 & 11.7 & $6.2 \pm 1.9$ \\
\hline Phosphate (mg/L) & 0.5 & 0.6 & 1.1 & 1.1 & $0.8 \pm 0.2$ \\
\hline
\end{tabular}


Table 3: Physico-Chemical Flux in the Mesohaline Creeks of Lagos Lagoon (April July, 2017)

\begin{tabular}{|c|c|c|c|c|c|c|c|}
\hline \multirow[b]{2}{*}{ Parameter } & \multicolumn{3}{|c|}{ Abule-Eledu Creek } & \multicolumn{3}{|c|}{ Abule-Agege Creek } & \multirow[b]{2}{*}{$P$-value } \\
\hline & Min & Max & $\begin{array}{c}\text { Mean } \pm \\
\text { SEM }\end{array}$ & Min & Max & $\begin{array}{c}\text { Mean } \pm \\
\text { SEM }\end{array}$ & \\
\hline Air Temperature $\left({ }^{\circ} \mathbf{C}\right)$ & 30 & 32 & $31.1 \pm 0.4$ & 30 & 32 & $31.4 \pm 0.5$ & 0.60 \\
\hline Water Temperature $\left({ }^{\circ} \mathbf{C}\right)$ & 27.5 & 31.1 & $29.7 \pm 0.8$ & 27.5 & 31.8 & $30.0 \pm 0.9$ & 0.82 \\
\hline Transparency $(\mathrm{cm})$ & 32.6 & 46.5 & $36.2 \pm 3.4$ & 32.6 & 46.5 & $36.2 \pm 3.4$ & 1.00 \\
\hline Rainfall (mm) & 110.6 & 431.7 & $241.9 \pm 6.4$ & 110.6 & 431.7 & $241.9 \pm 2.3$ & 1.00 \\
\hline pH at $25^{\circ} \mathrm{C}$ & 6.7 & 7.7 & $7.1 \pm 0.3$ & 6.6 & 7.6 & $7.1 \pm 0.2$ & 0.94 \\
\hline Conductivity $(\mu \mathrm{S} / \mathrm{cm})$ & 5478 & 29451 & $19154 \pm 9.7$ & 4393 & 30550 & $21808 \pm 8.2$ & 0.76 \\
\hline Total dissolved solid (mg/L) & 3253 & 16833 & $10901 \pm 6.2$ & 2637 & 17417 & $12725 \pm 2.9$ & 0.70 \\
\hline Total suspended solid (mg/L) & 11.8 & 16.3 & $13.7 \pm 1$ & 8 & 13.5 & $10.8 \pm 1.2$ & 0.11 \\
\hline Salinity (ppt, at $\left.25^{\circ} \mathrm{C}\right)$ & 3 & 17.2 & $11.1 \pm 3.2$ & 2.3 & 17.9 & $12.6 \pm 3.6$ & 0.77 \\
\hline Turbidity (NTU) & 9.6 & 21.1 & $14.2 \pm 2.5$ & 7.2 & 16.2 & $11.8 \pm 1.8$ & 0.47 \\
\hline Acidity (mg/L, CaC03) & 5.8 & 9.8 & $8.3 \pm 0.9$ & 3.9 & 7.1 & $5.8 \pm 0.7$ & 0.07 \\
\hline Alkalinity (mg/L,CaC03) & 138.9 & 148.7 & $144.4 \pm 2.2$ & 115.1 & 136.1 & $121.9 \pm 4.9$ & $0.01 *$ \\
\hline Dissolved oxygen (mg/L) & 5.1 & 5.6 & $5.3 \pm 0.1$ & 5.2 & 5.8 & $5.4 \pm 0.1$ & 0.53 \\
\hline Biological oxygen demand $(\mathrm{mg} / \mathrm{L})$ & 4.2 & 6.8 & $5.1 \pm 0.6$ & 2.5 & 7.5 & $4.9 \pm 1$ & 0.86 \\
\hline Chemical oxygen demand (mg/L) & 8.9 & 28 & $19.0 \pm 3.9$ & 6 & 29.3 & $18.5 \pm 5.3$ & 0.95 \\
\hline Nitrate $(\mathrm{mg} / \mathrm{L}$ as NO3) & 2.6 & 8.7 & $6.0 \pm 1.4$ & 2.6 & 11.7 & $6.2 \pm 1.9$ & 0.94 \\
\hline Phosphate $(\mathrm{mg} / \mathrm{L})$ & 0.6 & 2.5 & $1.5 \pm 0.4$ & 0.5 & 1.1 & $0.8 \pm 0.2$ & 0.19 \\
\hline
\end{tabular}

Keys: Min: Minimum, Max: Maximum, SEM: Standard Error of Mean, *: Significant difference at $\mathrm{P}<0.05$

\section{Composition and Abundance Crustacean Larvae:}

The variation in composition and abundance of crustacean larvae at the two mesohaline creeks of Lagos Lagoon between April and July, 2017 are presented in Table 4, Figs. 2 and 3. The crustacean larvae throughout the sampling period were represented by five orders namely: Cladocera, Mysida, Calanoida, Cyclopoida and Harpaticoida. A total of 126 and 340 individuals were recorded for Abule-Eledu and Abule-Agege creeks respectively. In Abule-Eledu Creek, Calanoida which were the most abundant accounted for 64 individuals which gave $51 \%$ of the total individuals recorded. The Cyclopoida recorded 31 (25\%), Cladocera recorded 26 (21\%), Harpaticoida recorded 5 (4\%) while Mysida recorded 1 (1\%).

In Abule-Agege Creek, Cyclopoida was the most abundant accounting for 153 individuals with $45 \%$ of the total individuals recorded. Calanoida was the second abundant order recording 124 individuals (36\%). The Cladocera recorded 42 (12\%), Harpaticoida recorded 12 (4\%) while Mysida recorded 9 (3\%). 
Table 4: Variations in Crustacean Larvae (cell $/ \mathrm{ml}$ ) Composition at Mesohaline Creeks of Lagos Lagoon (April - July, 2017)

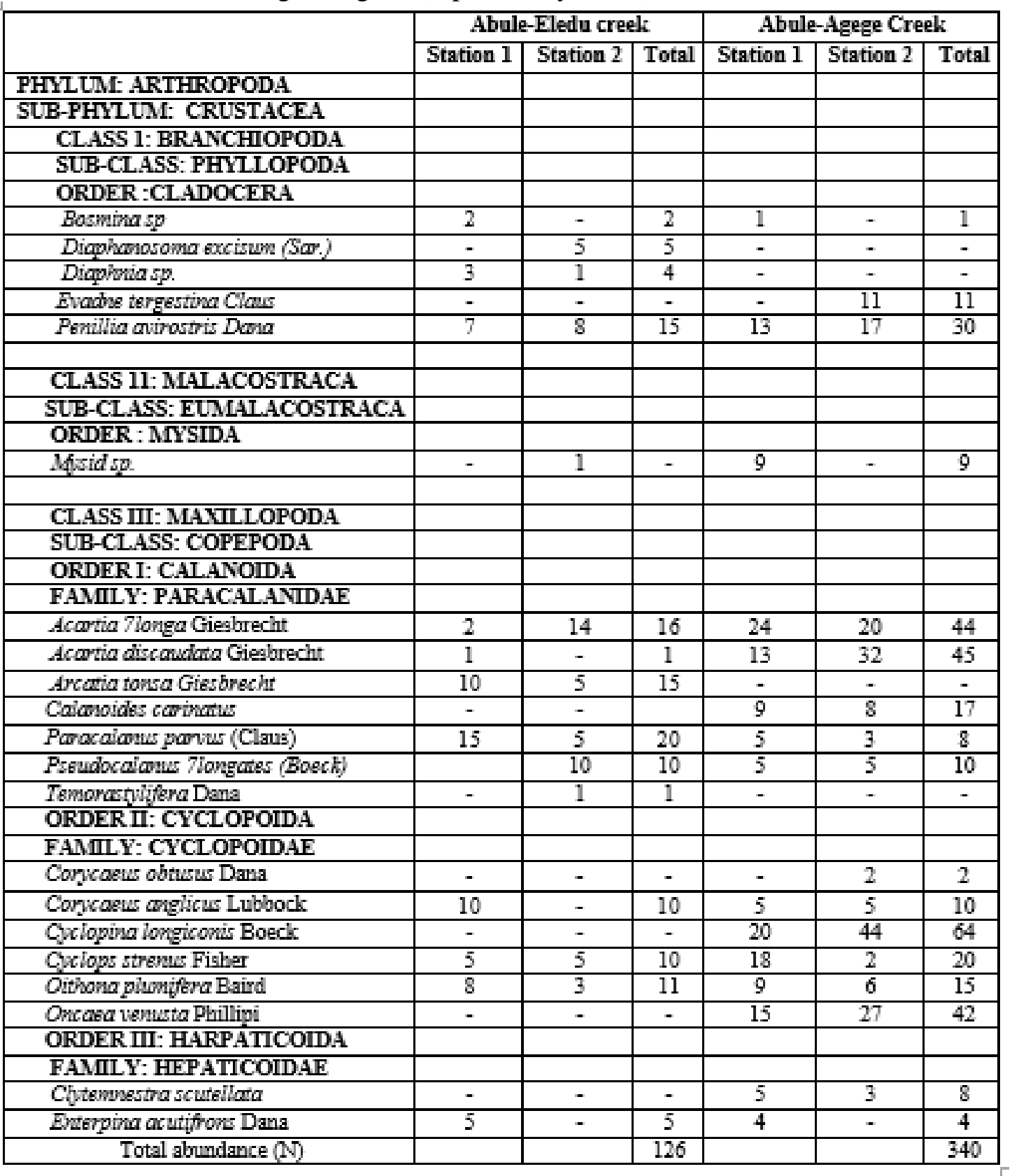

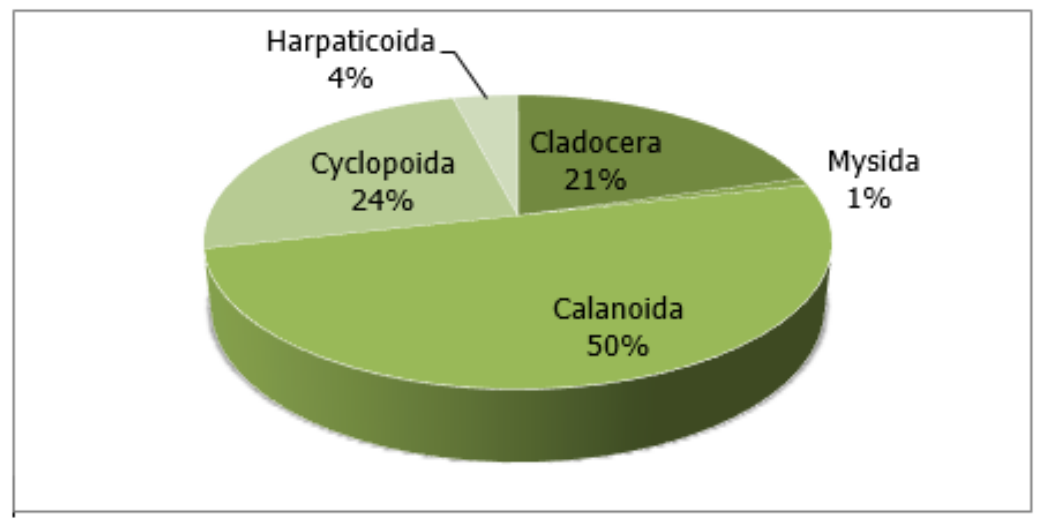

Fig. 2: Relative Abundance of Crustacean Larvae (Orders) in Abule-Eledu Creek of the Lagos Lagoon (April - July, 2017). 


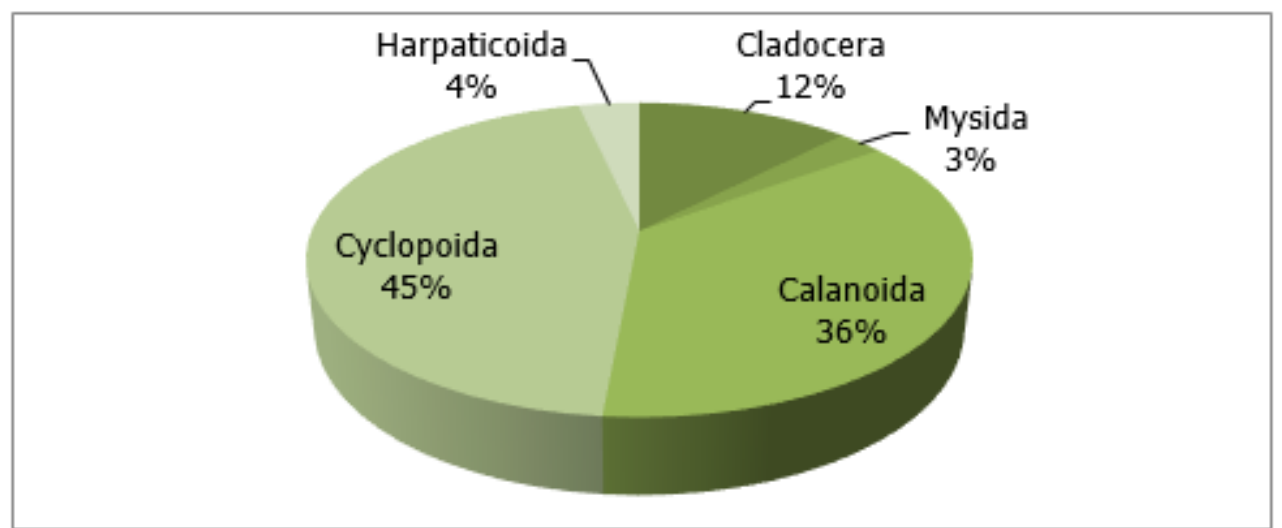

Fig. 3: Relative Abundance of Crustacean Larvae (Orders) in Abule-Agege Creek of the Lagos Lagoon (April - July, 2017).

\section{Crustacean Larvae Community Structure:}

The crustacean larvae community's eco-mathematical indices (biological indices) are presented in Table 5. Total species diversity (S) was14 in Abule-Eledu Creek and 17 in Abule-Agege Creek. There were relatively similar Shannon-Wiener Index (Hs) values for the two creeks ranging between 0.90 and 0.96 for Abule-Eledu Creek and between 0.97 and 1.09 for Abule-Agege Creek. With the exception of Menhinick Index (D) and Equitability Index (j), all other biotic indices were higher in Abule-Agege Creek than Abule-Eledu Creek.

Table 5: Crustacean Larvae Community Structure Indices in Mesohaline Creeks of Lagos Lagoon (April - July, 2017)

\begin{tabular}{|l|c|c|c|c|c|c|}
\hline & \multicolumn{3}{|c|}{ Abule-Eledu creek } & \multicolumn{3}{c|}{ Abule-Agege Creek } \\
\cline { 2 - 7 } & $\begin{array}{c}\text { Station } \\
1\end{array}$ & $\begin{array}{c}\text { Station } \\
2\end{array}$ & Combine & $\begin{array}{c}\text { Station } \\
1\end{array}$ & $\begin{array}{c}\text { Station } \\
2\end{array}$ & Combine \\
\hline Total species diversity (S) & 11 & 10 & 14 & 15 & 14 & 17 \\
\hline Total abundance (N) & 68 & 58 & 126 & 155 & 185 & 340 \\
\hline Log of Species diversity (Log S) & 1.04 & 1 & 1.15 & 1.18 & 1.15 & 1.23 \\
\hline Log of abundance (Log N) & 1.83 & 1.76 & 2.1 & 2.19 & 2.27 & 2.53 \\
\hline Shannon-Wiener Index (Hs) & 0.94 & 0.9 & 1.04 & 1.09 & 0.97 & 1.07 \\
\hline Menhinick Index (D) & 1.33 & 1.31 & 1.25 & 1.2 & 1.03 & 0.92 \\
\hline Margalef Index (d) & 2.37 & 2.22 & 2.69 & 2.78 & 2.49 & 2.74 \\
\hline Equitability Index (j) & 0.91 & 0.9 & 0.91 & 0.93 & 0.84 & 0.87 \\
\hline Simpson's Dominance Index (C) & 0.13 & 0.15 & 0.1 & 0.09 & 0.14 & 0.11 \\
\hline
\end{tabular}

\section{DISCUSSION}

The data for the physicochemical flux in this study confirms an earlier report by Emmanuel and Onyema (2007) and Lawal-Are et al. (2010), in which according to them, the diluting and enriching effects of floodwaters, inflow of lagoon brackish water hence the existence of environmental gradients, governs the distribution of creek and lagoon biota in South-Western Nigeria. The observed low air and water temperatures in July in both creeks may be due to the harmattan haze prevalent at the period and the possible increase in cloud cover that reduced isolation. Similar reports have been made on tidal creeks of south-west Nigeria (Chukwu and Nwankwo, 2004; Nwankwo, 2013). Nwankwo (1990) highlighted that seasonal variation in transparency 
in the coastal waters of South-Western Nigeria is linked to the rainfall pattern and associated floods. Furthermore, high transparency values confirm the known phenomenon that transparency and rainfall are inversely related to the region. The surface water $\mathrm{pH}$ values in both Abule-Eledu and Abule-Agege creeks were alkaline in dry months; this alkaline $\mathrm{pH}$ may be due to the buffering effects of the seawater (Onyema, 2007).

The observed increase in conductivity $(>190.40 \mu \mathrm{S} / \mathrm{cm})$ and salinity $(>10.50 \%)$ in the dry months for both creeks agreed with what is obtained in tidal creeks of SouthWest Nigeria (Adesalu et al., 2010). The conductivity values of the study sites increased with a rise in the total dissolved solids and a decrease in the total suspended solids. These variations to a large extent could be attributed to the effect of tidal seawater incursion and also freshwater input from adjoining creeks and land as expected during the dry season (Onyema, 2009). Salinity regimes in these mesohaline creeks have been related to rainfall distribution. According to Nwankwo (1996) and Onyema et al. (2006), salinity is an environmental barrier in the distribution of biota. The low dissolved oxygen values between April and May, low chemical oxygen demand values in July as well as low biological oxygen demand values in May and July could be an indication of the level of pollution in both Abule-Eledu and AbuleAgege creeks. According to Nwankwo et al. (2013), Biological oxygen demand values less than $2.0 \mathrm{mg} / \mathrm{L}$ indicate clean water, 2.0 to $4.0 \mathrm{mg} / \mathrm{L}$ indicate moderate pollution while above $8.0 \mathrm{mg} / \mathrm{L}$ indicate severe stress. In this regard, Abule-Agege Creek may be said to be more polluted than polluted although both exhibited moderate pollution. The high levels of nitrate may be due to the effect of direct discharges of pollutants and other biodegradable wastes into the coastal waters coupled with the enrichment of adjoining wetlands, creek and subsequent run-offs for the coastal water of SouthWestern Nigeria. The level of the phosphate during the period suggested nutrient enrichment required by plankton for growth and reproduction (Lawal-Are et al., 2010).

Crustacean zooplanktons were the key components of the plankton of the creek and according to Onyema and Popoola (2013), zooplankton spectrum in the Lagos Harbour varied with season and that recruitment was mainly from the sea. The Calanoida and Cyclopoida were the most frequent and notable orders occurring in Abule-Eledu and Abule-Agege creek respectively. Other crustacean larvae categories such as Mysida, Calanoida and Harpaticoida were also recorded. According to LawalAre (2010) and Moruf and Lawal- Are (2017), crabs are known to begin the early stages of their lives in estuarine systems which are regarded as "nursery grounds". They also point to the suitability of the water quality characteristics of the creek to sustain diverse aquatic life. The chordate (Oikopleura dioica), arrow worm (Sagitta enflata) and the jellyfish are likely pointers of an array of planktonic faunal components that inhabit the creek at varying time of the year especially from the sea via the Lagos lagoon. According to Onyema et al. (2006) in a study of diatoms and dinoflagellates recorded from the Lagos Lagoon reported that the source of recruitment of the lagoonal dinoflagellates was the adjacent sea since most reported species were warm-water oceanic forms.

Higher values of species diversity, abundance, Shannon-Wiener Index (Hs), Margalef Index (d) and Simpson's Dominance Index (C) were recorded especially in Abule-Agege Creek. High values of the diversity index indicated that the species were more evenly dispersed. The occurrence of higher values of copepod populations confirmed that crustacean copepods are the taxonomically more important zooplankton group in the Lagos Lagoon and adjoining water systems. Similarly, Onyema et al. (2007) are of the view that although diatoms dominated the phytoplankton spectrum, 
copepods (Calanoida) were prominent members of the zooplankton assemblage of the Lagos lagoon. A large number of smaller zooplankton species may possibly be due to predation pressure from planktivorous fishes that selectively prey on larger sized zooplankton (Imoebe and Adeyinka, 2010). Rosemond et al. (1993) say that the ability to adapt to food conditions and less predation may be the reasons for the significant abundance of rotifers, cladocera and copepods in the many tropical water bodies. This study therefore suggests that Calanoida and Cyclopoida which are orders of the Subclass Copepoda were the dominant crustacean larvae group in the creeks of the Lagos Lagoon.

\section{ACKNOWLEDGMENTS}

The second author is thankful to Dr (Mrs) Titilade Akanmu, a phycologist in the Department of Marine Sciences, University of Lagos for providing materials for this manuscript.

\section{REFERENCES}

Addis, A., Francesca, B., Antonello, F., Emiliana, P. and Marcella, C. (2007). Larval development of Lightiella magdalenina (Crustacea, Cephalocarida). Marine Biology. 152 (3): 733-744.

Adesalu, T.A., Bagbe, M. and Keyede, D. (2010). Hydrochemistry and phytoplankton composition of two tidal creeks in South western Nigeria. Int .J .Trop. Biol. 58: 827-840.

Ahmad, U., Parveen, S., Khan, A.A., Kabir, H.A., Mola, H.R.A. and Ganai, A.H. (2011). Zooplankton population in relation to physico-chemical factors of a sewage-fed pond of Aligarh (UP), India. BLM 3 (SI2): 336-341.

Alexander, R., (2012). Interactions of zooplankton and phytoplankton with cyanobacteria. Univ. Nebraska, 69 pp.

APHA. (2005). Manual of Standard Methods for Examination for Water and Waste water. 14th Edition. Washington Dc. pp. 121-132.

Chukwu, L.O. and Nwankwo, D.I. (2004). The impact of land based pollution on the hydrochemistry and benthic community of tropical West Africa creek. Ekologia. 2:1-9.

Edokpayi, C.A. and Nkwoji, J.A. (2007). Annual changes in the physico-chemical and macrobenthic invertebrate characteristics of the Lagos lagoon sewage dump site at Iddo, Southern Nigeria. Ecology, Enironment \& Conservation. 13(1): 13-18.

Emmanuel, B.E. and Onyema, I.C. (2007). The plankton and fishes of a tropical creek in south-western Nigeria. Turkish Journal of Fisheries and Aquatic Sciences. 7: 105-114.

Goswami, S.C. (2004). Zooplankton Methodology Collection and Identification - a Field Manual: National Institute of Oceanography, Dona Paula, Goa- 403004 Pp58.

Hall, C.J. and Burns, C.W. (2001). Effects of salinity and temperature on survival and reproduction of Boeckella hamata (Copepoda: Calanoida) from a periodically brackish lake. J. Plankton Res. 23 (1): 97-103.

Imoobe, T.O.T. and Adeyinka, M.L. (2010). Zooplankton- Based Assessment of the Trophic State of a Tropical Forest River. International Journal of Fisheries and Aquaculture. 2(2): 64-70. 
Lawal-Are, A.O., Onyema, I.C. and Akande, T.R. (2010). The Water Chemistry, Crustacean, Zooplankton and Some Associated Fauna Species of aTropical Tidal Creek in Lagos, Nigeria. Journal of American Science. 6 (1):81-90.

Lawal-Are, A.O. (2010). Reproductive Biology of the Blue Crab, Callinectes amnicola in the Lagos Lagoon, Nigeria. Turkish Journal of Fish and Aquatic Science. 10:1-7.

Lynne, M.W. (2004). Aquatic Invertebrate Taxonomist, Cooperative Freshwater Ecology Unit. 2nd edition, Laurentian University pp $32-44$.

Moruf, R.O. and Lawal-Are, A.O. (2015). Growth Pattern, Whorl and Girth Relationship of the Periwinkle, Tympanotonus fuscatus var radula (Linnaeus, 1758) from a Tropical Estuarine Lagoon, Lagos, Nigeria. International Journal of Fisheries and Aquatic Studies. 3 (1): 111-115.

Moruf, R.O. and Lawal-Are, A.O. (2017). Comparability in dietary elements, sex ratio and fecundity of portunidae crabs, Callinectes amnicola (De Rochebrune) and Portunus validus (Herklots) off Lagos Coast. Journal of Aquatic Sciences. 32 (1A): $25-31$.

Nkwoji, J.A., Onyema, I.C. and Igbo, J.K. (2010). Wet season spatial occurrence of phytoplankton and zooplankton in Lagos Lagoon, Nigeria. Science World Journal. 5 (2): $7-14$.

Nwankwo, D. I. (1990). Contribution to the Diatom flora of Nigeria. Diatoms of Lagos lagoon and the adjacent sea. Nigerian Journal of Botany. 3: 53-70.

Nwankwo, D.I. (1996). Phytoplankton diversity and succession in Lagos Lagoon, Nigeria. Archiv fur Hydrobiologie. 135 (4): 529-542.

Nwankwo, D.I., Adesalu, T.A., Amako, C.C, Akagha, S.C and Keyede, J. D. (2013). Temporal variations in water chemistry and chlorophyll- $a$ at the Tomaro Creek, Lagos, Nigeria. Journal of Ecology and the Natural Environment. 5(7): $144-151$.

Ogbeibu, A.E. (2005). Biostatistics: A practical approach to research and data handling. Mindex Publishing Company limited, Benin city, Nigeria.264pp..

Onyema, 1.C., Okpara, C.U., Ogbebor, C.I., Otudeko, O. and Nwankwo, D.I. (2007). Comparative studies of the water chemistry characteristics and temporal plankton variations at two polluted sites along the Lagos lagoon, Nigeria. Ecology, Environment and Conservation. 13: $1-12$.

Onyema, I.C and Popoola, R.T. (2013). The physico-chemical characteristics, chlorophyll- $a$ levels and phytoplankton dynamics of the east mole area of the Lagos Harbour, Lagos. Journal of Asian Scientific Research. 3(10): 995-1010.

Onyema, I.C. and Ojo, A.A. (2008). The zooplankton dynamics and chlorophyll a concentration of a tropical tidal creek in relation to water quality indices. Life Science Journal. 5 (4): 7-14.

Onyema, I.C. (2007). Mudflat microalgae of a tropical bay in Lagos, Nigeria. Asian Journal of Microbiology, Biotechnology and Environmental Sciences. 9 (4): 877 883.

Onyema, I.C. (2009). Notes on the existence of an additional lagoon in Southwestern Nigeria: Apẹsẹ Lagoon. Journal of American Science. 5(4): 151-156.

Onyema, I.C., Nwankwo, D.I. and Oduleye, T. (2006). Diatoms and dinoflagellates of an estuarine creek in Lagos. Journal of Scientific Research Development. 10: $73-82$.

Rosemond, A.D., Mulholl, P. and Elwood, J.W (1993). Topdown and Bottom-up control of stream periphyton: effects of nutrients and herbivores. Ecology, 74: $1264-1280$. 
Rota-Stabelli, O., Ehsan Kayal, D.G., Jennifer, D., Jeffrey, L.B., Maximilian, J.T., Davide, P., Mark, B. and Dennis, V.L. (2010). Ecdysozoan Mitogenomics: Evidence for a Common Origin of the Legged Invertebrates, the Panarthropoda". Genome Biology and Evolution 2: 425-440.

Sanet, J.V., Jonathon, T., Carin, V.G. and Annelise, G. (2006). Easy Identification of the Common Fresh Algae: A Guide for the Identification of Microscopic Algae in Southern Fresh Waters, North West University, Potchefsroom, Pretoria. Pp 31- 44.

Suthers, I.M. and Rissik, D. (2009). Plankton: A Guide toheir Ecology and Monitoring for Water Quality. CSIRO Publishing, Collingwood, Vic., Pp: 272.

Verlencar, X.N and Desai, S. (2004). Phytoplankton Identification Manual. National Institute of Oceanography New Delhi, 1st ed Pp 4.

Wetzel, R.G and Liken, G.E. (2000). Limnological Analyses. Third Edition. Springer, New York pp 429. 